\title{
The Growth of Purine Mutants of Bacillus anthracis in the Body of the Mouse
}

\author{
By G. IVÁNOVICS, ELIZABETH MARJAI AND A. DOBOZY \\ Institute of Microbiology, Medical University, Szeged, Hungary
}

(Accepted for publication 26 March 1968)

\begin{abstract}
SUMMARY
Auxotrophic mutants of Bacillus anthracis with a specific requirement for adenine in their phenotype were isolated and the block in the purine pathway determined by enzymic activity of preparations obtained from the individual strains. The adenine-dependent mutants could be classed into two groups: one group was of strains devoid of any adenylosuccinate synthase (EC 6.3.4.4) activity; the presence of adenylosuccinate lyase (EC 4.3.2.2) activity was not detected in the strains of the other group. In these latter strains a single gene locus controls the two enzyme activities involved in the purine pathway, as established for other organisms.

None of the adenine-dependent strains was capable of killing mice although they were given a toxic dose of adenine at challenge. Reversion to prototrophy restored full virulence. The lack of proliferation of the adeninedependent bacteria in the host could not be explained simply by a shortage of available adenine in the body of the mouse, since the adenine intake provided a certain concentration of this base at the inoculation site, in the peritoneal cavity, and in the blood stream. In spite of the fact that adeninedependent mutants were producing both of the known aggressins, namely capsule and toxin, they were not capable of invading the blood stream or of multiplying there. It is assumed that something essential for invasion of the host was not produced by adenine-dependent mutants. The lack of this hypothetical factor rendered these organisms highly vulnerable to the defence mechanism of the host. In contrast to the adenine-dependent mutants, purine auxotrophs blocked either in the early part of the purine pathway or in the conversion of xanthylic acid to guanylic acid were found to grow readily in the body of the mouse, even in the absence of an exogeneous supply of purine bases. It is suggested that purine bases needed by these mutants for their growth might originate from an influx of purines from tissues damaged by the bacteria.
\end{abstract}

\section{INTRODUCTION}

Approximately 200 isolates with essential requirements either for nucleic acid bases or vitamins were obtained from a non-capsulated mutant of Bacillus anthracis, strain volluM, in this laboratory (Ivánovics, Varga \& Marjai, 1963). The reversion of the isolates to a capsulated form did not involve any change in the nutritional requirements of the mutants (Ivánovics \& Marjai, I964). When the capsulated forms of the auxotrophs were tested for their virulence in the mouse, all of the pyrimidine-dependent (uracil, thymine), or vitamin-dependent, strains were found to be fully virulent (Ivánovics \& Marjai, 1964; and unpublished observations). Auxotrophic strains with a purine requirement showed a different pattern of pathogenicity, according to the deficiency in the de novo purine pathway. Strains which showed a block in the early

Vol. 53, No. 1, was issued 1o September 1968. 
part of the purine pathway, where the requirement could be met by any of the purines hypoxanthine, xanthine, adenine or guanine, did not have a significant impairment of their virulence. Similarly, strains which required guanine specifically for growth also killed mice, although an exogeneous supply of guanine after infection of the animals enhanced the virulence of the bacteria. In contrast, auxotrophs which were adeninedependent in their phenotype were not lethal to mice, even when a heavy inoculum ( $10^{6}$ spores) was injected and supplementary adenine given after infection.

It was not possible to maintain a high concentration of adenine during the whole course of a conventional virulence test ( 2 weeks) because of the high turnover rate (Bennet, I953; Schwarz \& Rieke, 1963) and the toxicity of adenine (Raska, 1946; Brown, Roll \& Plentl, 1947). The investigations presented in the present paper were made to devise short-term experiments during which as high a concentration as possible of adenine was maintained in the infected animals. It was noted by Philips, Thiersch \& Bendich (1952) that death occurred 2-4 days after the administration of a lethal dose of adenine because of the deposition in the kidneys of 2,8-dioxy-adenine, a crystalline oxidation product of adenine produced in vivo. Thus, it was possible to follow the multiplication of the adenine-dependent bacteria in the peritoneal cavity during the interval of a few days between administration of the adenine and death of the animal.

An adenine-dependent mutant in our designation (Ivánovics \& Marjai, 1964) means that the conversion of inosinic acid to adenylic acid was blocked in that strain. This conversion takes place by two enzymic reactions: in the first, inosinic acid is converted to the ribotide of adenylosuccinate; in the second, adenlyic acid is formed. Attempts were made to isolate and use both types of mutants, lacking either the first or the second enzymic reaction, in the virulence tests.

\section{METHODS}

Bacterial strains. The isolation and some characteristics of the purine auxotrophs of Bacillus anthracis were described earlier (Ivánovics et al. 1963). Several recently isolated adenine-dependent mutants were also included in this study. As a safety measure, non-capsulated $\left(\mathrm{C}^{-}\right)$forms of auxotrophs were preferred to the capsulated $\left(\mathrm{C}^{+}\right)$in certain experiments, such as the isolation of enzyme preparations. (see Table I).

For the designation of individual purine auxotrophic strains, the nomenclature recommended by Demerec, Adelberg, Clark \& Hartman (I966) could not be fully adopted since no genetic tool was available for recombination tests in Bacillus anthracis. Nevertheless, the use of this nomenclature was adopted as far as possible. The locus involved by mutation could be inferred either from the phenotype or from the altered enzymic activity of the mutants. Auxotrophs having a block before purine ring closure (inosinic acid) were symbolized by pur, whereas ade and gua mean that the conversion of inosinic acid either to adenylic acid or to guanylic acid was blocked. Biochemical investigations of ade mutants pointed to the site involved by mutation, and these mutants were divided accordingly into groups designated by roman numerals I and II. An arabic numeral affixed to the symbol with a hyphen indicated the individual origin of the mutants. Some of the prototrophic revertants of adenine auxotrophs were also included in this study, but whether their wild-type phenotype was due to back mutation of the affected nucleotides or to a suppressor mutation was not known. 
Prototrophic revertants were isolated from the capsulogenic form of ade mutants. Thus, revertants were obtained from the following strains: ade $\mathrm{II}-3 \mathrm{C}^{+}$; ade $\mathrm{II}-4 \mathrm{C}^{+}$; ade $\mathrm{I}-\mathrm{I} \mathrm{C}^{+}$; and ade $\mathrm{I}-2 \mathrm{C}^{+}$.

Chemicals. Commercial preparations were used; purine bases and nucleotides were purchased from Reanal (Budapest) or Fluka AG (Buchs, Switzerland). Adenine was recrystallized and its purity checked by thin-layer chromatography. The ammonium salt of adenylosuccinic acid was a gift of Dr Haruo Momose (Central Research Laboratories, Ajinomoto Co., Ltd., Kawasaki, Japan).

\section{Table I. Bacillus anthracis: list of strains used}

\begin{tabular}{|c|c|c|c|}
\hline $\begin{array}{l}\text { Serial no. } \\
\text { of isolate } \\
\text { (parent) }\end{array}$ & $\begin{array}{l}\text { Designation } \\
\text { of strain* } \\
\left(\mathrm{VC}^{+}\right)\end{array}$ & $\begin{array}{l}\text { Phenotype, } \\
\text { purine } \\
\text { requirement } \\
\text { (prototrophic) }\end{array}$ & $\begin{array}{c}\text { Former } \\
\text { designation } \ddagger \\
\text { (strain voLLUM) }\end{array}$ \\
\hline sz 6I & pur-I & Any purine & 6I $C^{-}$hy- \\
\hline SZ 30 & $g u a-I^{\dagger}$ & Guanine & $30 \mathrm{C}^{-} \mathrm{gu}^{-}$ \\
\hline sz 6 & ade II-I & & $6 \mathrm{C}^{-} \mathrm{ad}^{-}$ \\
\hline SZ 20 & ade II-2 & & $20 \mathrm{C}^{-} \mathrm{ad}^{-}$ \\
\hline SZ 23 & ade II-3 & Adenine & $23 \mathrm{C}^{-} \mathrm{ad}^{-}$ \\
\hline sZ2I 4 & ade II-4 & Ademine & 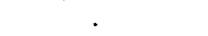 \\
\hline SZ34I & ade I-I & & . \\
\hline sz 344 & ade I-2 & & . \\
\hline
\end{tabular}

* Both capsulogenic $\left(\mathrm{C}^{+}\right)$and non-capsulogenic $\left(\mathrm{C}^{-}\right)$forms of the strains were used in this study. $\uparrow$ Xanthine could not be substituted for guanine.

+ See Ivánovics \& Marjai (1964).

Media. A basal casein-hydrolysate medium (BCM) was used for growing auxotrophs under defined conditions; it contained thiamine $\mathrm{I} \mu \mathrm{g} . / \mathrm{ml}$. and was prepared as previously described (Ivánovics et al. 1963). In some cases BCM supplemented with additional metabolites (referred to as CCM) was also used (Ivánovics, I964). A nondefined yeast-extract peptone medium (YP) was identical with that used in this laboratory (Cziszár \& Ivánovics, 1965).

Cultivation of the bacteria. The bacteria were grown in liquid or on solid medium as previously described (Ivánovics et al. 1963; Ivánovics, 1964).

With few exceptions, standard spore suspensions were used for both virulence tests and as inoculum for obtaining cultures for enzyme preparation. Spore suspensions were made by inoculating several slopes of YP agar from a single colony, followed by incubation at $37^{\circ}$ for 8 to Io days. Each culture was washed off with phosphate buffer (O.0I $\mathrm{M} ; \mathrm{pH} 7$ ) separately and centrifuged; the pellet was resuspended in buffer and digested in a water bath at $47^{\circ}$ for $3 \mathrm{hr}$. Following this, the suspensions were centrifuged and the pellets taken up in distilled water. Each lot of spore material, corresponding to one agar slope, was tested for the presence of prototrophic revertants by inoculating about $10^{7}$ spores on $\mathrm{BCM}$ agar. Those lots which yielded colonies were discarded; the remainder were pooled and stored at $4^{\circ}$.

Enzyme preparations and their assay. Two enzymes, adenylosuccinate synthase (EC 6.3.4.4), and adenylosuccinate lyase (EC 4.3.2.2), are involved in the conversion of inosinic acid to adenylic acid. To isolate these enzymes from prototrophs and various adenine-dependent mutants, a bacterial suspension was used, grown with vigorous shaking in CCM containing adenine 20 to $40 \mu \mathrm{g} . / \mathrm{ml}$. Bacillus anthracis is 
known to produce extracellular proteolytic enzyme, the maximal release of which is at the end of the logarithmic growth phase. By harvesting the bacteria at early stationary phase and washing, one could rid the preparation of most of this proteolytic enzyme. One hundred $\mathrm{ml}$. of culture yielded about $\mathrm{I} \mathrm{g}$. washed sediment.

Preparations with adenylosuccinate synthase activity were obtained by a slightly modified method, similar to that recommended by Lieberman (1956) for Escherichia coli. Washed bacteria ( 4 to $5 \mathrm{~g}$. wet wt) were suspended in $25 \mathrm{ml}$. of $0.005 \mathrm{M}-\mathrm{K}_{2} \mathrm{HPO}_{4}$ which contained gelatin I \% $(\mathrm{w} / \mathrm{v})$; the suspensions were treated ultrasonically in a MSE Ultrasonic Power unit at $2^{\circ}$ to $4^{\circ}$ for 15 min. The extract thus obtained was processed by the technique of Lieberman (1956). The gelatin, which protected adenylosuccinate synthase against proteolytic enzyme in the early phase of manipulation, was removed during the ammonium sulphate precipitations. The final product, termed 'low pH fraction' was used for estimating the enzyme activity of the bacteria, the assay of enzyme being done by Lieberman's 'Assay I' (1956). Assay systems containing various amounts of enzyme preparation were incubated at $37^{\circ}$ for $30 \mathrm{~min}$. The unit of activity $(0 . \mathrm{I}$ increase in extinction at $280 \mathrm{~m} \mu)$ was calculated by interpolations of experimental data. The protein content of the enzyme preparations was estimated by the method of Lowry, Rosebrough, Farr \& Randall (I95I). The specific activity was then recorded as units/mg. protein.

To detect the presence of adenylosuccinate lyase in individual adenineless mutants, extracts were obtained by ultrasonic treatment from the bacteria as described above, except that no gelatin was added to the suspensions. The addition of streptomycin sulphate $\mathrm{I} \%$ to the extract caused a heavy precipitate which was removed by centrifugation. The clear supernatant fluid, termed 'crude extract', was assayed for adenylosuccinate lyase, as recommended by Carter \& Cohen (I956) for enzyme preparations from yeast. Activity was measured from the rate of spectral change induced by the enzyme in a solution of the ammonium salt of adenylosuccinate ribotide. The change in extinction at $280 \mathrm{~m} \mu$ was constant in the first $2 \mathrm{~min}$. The initial velocity was calculated, and I unit of activity defined as the amount of enzyme necessary to decrease the extinction by $\mathrm{I} \cdot \mathrm{O} / \mathrm{min}$.

Accumulation of diazotable arylamines by non-proliferating suspensions of bacteria. In essence, the method of Gots \& Love (1954) was followed. Bacteria were grown with vigorous shaking in $\mathrm{BCM}+$ adenine $5 \mu \mathrm{g}$. $/ \mathrm{ml}$. Overnight cultures were centrifuged, the deposit washed with saline, and the bacteria resuspended in BCM diluted I/10 with saline; the addition of $0.4 \%$ glucose and thiamine $\mathrm{I} \mu \mathrm{g} . / \mathrm{ml}$. completed the system. Each ml. of suspension contained equiv. $0.5 \mathrm{mg}$. dry wt bacteria. After aeration for $3 \mathrm{hr}$ at $37^{\circ}$, the bacteria were centrifuged down and the supernatant fluid tested for diazotable arylamines by the Bratton \& Marshall (1939) procedure as recommended by Ravel, Eakin \& Shive (1948). The diazonium salt of 5-amino-4-imidazole-Nsuccino-carboxamide ribonucleotide (SAICAR) is very unstable. Lukens \& Buchanan (1959) recommended a procedure in which SAICAR gives a stable colour substance with the coupling agent. When parallel assays were made with the Bratton-Marshall. procedure and that recommended by Lukens \& Buchanan (I959), the results of the two tests were a good indication for the presence of SAICAR.

Production and assay of the toxin. A basal medium made of Casamino acid as recommended by Professor H. Smith, (Birmingham, England; personal communication) was used for toxin production. The medium was buffered with $0.8 \%(\mathrm{w} / \mathrm{v})$ 
$\mathrm{NaHCO}_{3}$ and $25 \mathrm{mg}$. charcoal was added to each $100 \mathrm{ml}$. In the case of an adenineless mutant, the medium contained adenine $20 \mu \mathrm{g} . / \mathrm{ml}$.

An inoculum of $10^{2}$ colony-forming vegetative bacteria was added to $50 \mathrm{ml}$. medium in a $250 \mathrm{ml}$. Erlenmeyer flask and incubated statically at $37^{\circ}$ for 20 to $22 \mathrm{hr}$. Horse serum $(10 \%, \mathrm{v} / \mathrm{v})$ was added to the supernatant fluid culture and the liquid sucked through a membrane filter (no. 4, Göttingen). Culture filtrates were assayed by intradermal inoculation into guinea-pigs (Smith, Keppie \& Stanley, 1955) and by an agar diffusion method (Thorne \& Belton, 1957; Sargeant, Stanley \& Smith, 1960), with an antitoxic horse serum kindly supplied by Professor H. Smith.

Assay of multiplication of the bacteria in the peritoneal cavity of the mouse. Spores were pre-germinated in tryptone broth for $30 \mathrm{~min}$. at $37^{\circ}$ and firmly pelleted by centrifugation. The pellet was resuspended in saline containing the appropriate base at $2 \mathrm{mg} . / \mathrm{ml}$., the colony count of the suspension being $10^{7} / \mathrm{ml}$. Mice ( 25 to $30 \mathrm{~g}$.) were inoculated intraperitoneally with $0.5 \mathrm{ml}$. of this material. Control groups were infected with pre-germinated spores suspended in saline. Because of the poor solubility of guanine, finely dispersed suspensions of this base in saline were used for preparing inocula.

When encapsulated bacilli were used for infection, a $20 \mathrm{hr}$ agar culture, grown in the presence of $20 \%(\mathrm{v} / \mathrm{v}) \mathrm{CO}_{2}$ in air (Ivánovics, I962), served as source of inoculum. Bacterial suspensions prepared from mucoid colonies were standardized by their turbidity. The chain-lengths of the bacteria and the number of colony-formers in the suspension were estimated simultaneously with the infection of mice.

Multiplication of the bacteria in the peritoneal cavity was followed by sacrificing two mice at intervals. The mice were killed by chloroform, the abdominal cavity rinsed with $5 \mathrm{ml}$. saline, and samples of pooled material plated in duplicate on YP agar. The animals kept for further observation were repeatedly injected intraperitoneally with $0.5 \mathrm{mg}$. of base. The total number of animals infected was 4 to 6 mice more than those sacrificed for assaying the colony counts; these extra animals served to estimate the survival period after infection. In some experiments, purine was given subcutaneously in an oily suspension $40 \mathrm{~min}$. before infection.

The bacterial count of the blood was estimated on a freshly drawn and citrated sample of heart blood. Direct smears from the peritoneal surface served to ascertain the morphological and staining characteristics of the bacilli. The slides were stained with Giemsa solution after ether fixation.

Mice found dead were not assayed for colony count because of the fibrin clot which aggregated individual bacilli. However, in these cases, heart blood was plated on both YP and BCM agar to establish the cause of death and to exclude reversion of bacteria to prototrophy. Death of an animal with a sterile blood culture was considered to have been caused by the toxicity of adenine.

Detection of adenine and guanine in the body of mice injected with these purines. After the intraperitoneal injection of adenine, peritoneal washings of the mice were collected, adjusted to $\mathrm{pH}_{4}$ with dilute acetic acid, and heated in a boiling water bath for $15 \mathrm{~min}$. The centrifuged and neutralized extracts were assayed for adenine by the method of Ivánovics (1964).

The presence of adenine in blood plasma was detected as follows. After the subcutaneous injection of adenine in oil, heart blood was withdrawn from the mice under deep chloroform anaesthesia. The blood was added to a cooled centrifuge tube con- 
taining heparin, and centrifuged. To a paraffin-coated test-tube $(160 \times 16 \mathrm{~mm}$.) were added $0.4 \mathrm{ml}$. of plasma and $0.2 \mathrm{ml}$. of BCM, and the whole inoculated with a spore suspension of strain ade II-3 (inoculum size 2 to $4 \times 10^{4}$ spores $/ \mathrm{ml}$.). The tubes were rotated horizontally (I revolution/Io min.) in an incubator at $37^{\circ}$ for $24 \mathrm{hr}$, and a colony count then made by plating on YP agar. Because of chain formation, the actual number of bacilli was approximately Io times greater than the colony count. A similar method served to determine guanine in blood plasma of mice not given guanine; strain $g u a-\mathrm{I}$ was then used as the assay organism.

\section{RESULTS}

Biochemical characteristics of adenine-dependent mutants of Bacillus anthracis

The adenine requirement of isolates sz6, sz20, sz 23, sz 214, sz 34I and sz 344 was highly specific; adenine could not be replaced by any of other purine. Growth of these strains in liquid $\mathrm{BCM}$ was initiated by a few $\mu \mathrm{g}$. of adenine $/ \mathrm{ml}$.; the growth response reached its peak in a static culture with about $20 \mu \mathrm{g} . / \mathrm{ml}$. Adenosine could replace adenine, but the phosphatides of this nucleoside were only partly and slowly utilized. Strains of adenine-dependent mutants could be divided into two groups (I, II), according to their enzyme activity (see Table 2).

Table 2. Bacillus anthracis: enzymic activity of preparations obtained from individual isolates of adenine-requiring auxotrophs

No. of
isolate
sz6
sz 20
Sz 23
SZ 214
Sz3 14
Sz344
VC-1

$\overbrace{\text { A. synthase }}^{\text {Specific enzymic activity* }} \begin{array}{cc}\text { A. lyase } \\ 28 & 0.00 \\ 27 & 0.00 \\ 38,32 & 0.00 \\ 23 & 0.00 \\ 0,0 & 0.27 \\ 0 & 0.31 \\ 31,26,28 & 0.35\end{array}$

\section{Accumulation of arylamines}

$\begin{array}{cc}\text { B.M. } & \text { L.B. } \\ - & + \\ - & + \\ - & + \\ - & + \\ - & - \\ - & - \\ - & -\end{array}$

* Adenylosuccinate synthase and adenylosuccinate lyase respectively. Numbers show the results of individual experiments.

$\dagger$ Non-capsulogenic form of wild type, $\mathrm{VC}^{+}$.

+ B.M. = Bratton-Marshall, L.B. = Lukens-Buchanan procedure. Extinction of colour substance at $560 \mathrm{~m} \mu$ in $\mathrm{r} \mathrm{cm}$. cuvette amounted to 0.03 to 0.09 in individual experiments with different strains.

An effective enzyme preparation with adenylosuccinate synthase activity was obtained from strains belonging to group II (isolates sz6, sz 23, sz214). The specific activity of the enzyme preparations was considerably lower than that of the "low $\mathrm{pH}$ fraction' obtained from Escherichia coli в by Lieberman (1956). For comparison $E$. coli $\mathrm{B}$ was also included in our study; the specific activity of 'low $\mathrm{pH}$ fraction' obtained from this strain was of the same order as those obtained from Bacillus anthracis.

In contrast, we did not find any adenylosuccinate lyase activity in extracts of Bacillus anthracis strains belonging to group II. Non-proliferating bacteria of these strains did not accumulate any substance giving a positive result with the original Bratton-Marshall test. On the other hand, an excretion of diazotable arylamine was detected by the procedure of Lukens \& Buchanan (1959). This was a good indication for accumula- 
tion of SAICAR. There is now strong evidence that the cleavage of both adenylosuccinate ribotide and 5-aminoimidazole-4-N-carboxamide ribotide (an early intermediate of purine synthesis) are catalysed by the same enzyme protein (EC 4.3.2.2) in mammalian tissues, in Neurospora crassa (Giles, Partridge \& Nelson, 1957), and in some species of Enterobacteriaceae (Gots \& Gollub, 1957; Gollub \& Gots, 1959). This special case where a single gene locus controls two enzymic reactions is also true for B. anthracis.

The Bacillus anthracis isolates Sz 34 I and Sz 344 formed another group (group I) of adenine-dependent mutants in which the enzyme adenylosuccinate synthase is missing in an effective form, whilst lyase activity can be detected in the crude extracts of bacteria. Supernatant fluids of non-proliferating bacterial suspensions of these strains contained a substance absorbing in the ultraviolet range with a peak at $248 \mathrm{~m} \mu$ at $\mathrm{pH} \mathrm{2}$; this maximum corresponds to that of inosinic acid. This accumulation of inosinic acid is in accordance with a block in the locus which controls adenylosuccinate synthase.

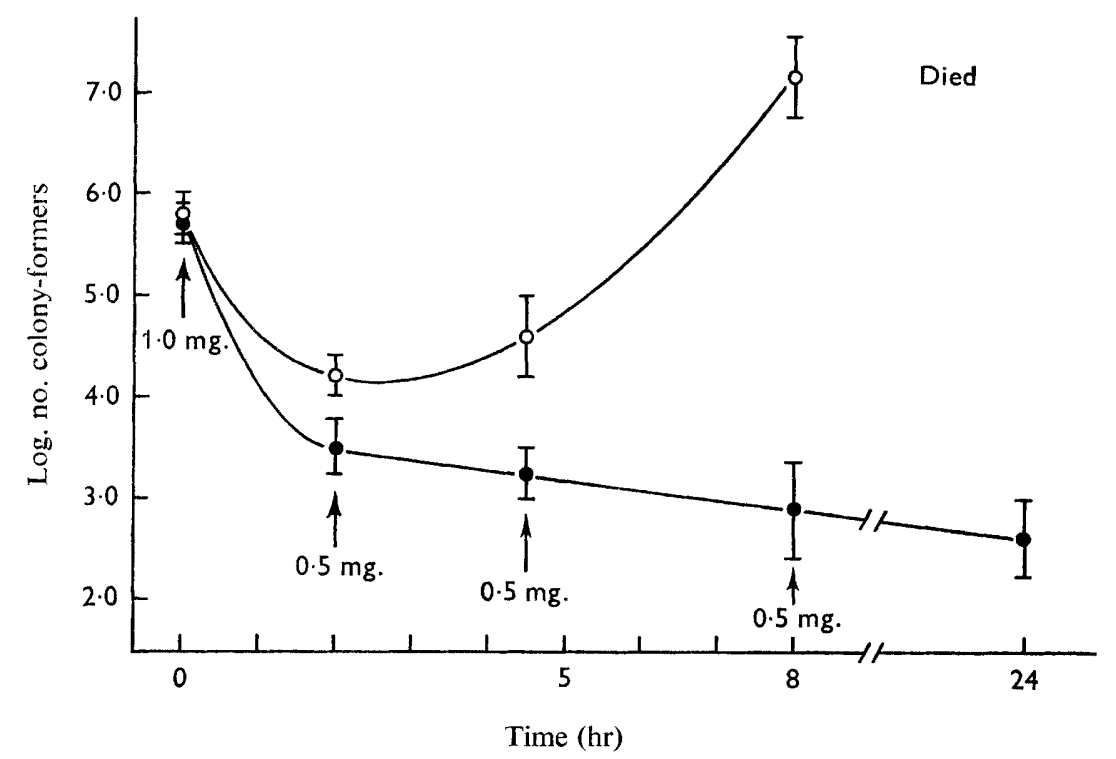

Fig. I. Bacillus anthracis: number of colony-formers in the peritoneal cavity of mice infected with $5 \times 10^{6}$ pre-germinated spores of strain ade $\mathrm{II}-3 \mathrm{C}^{+}$or of its prototrophic revertant. -, Strain adeII-3 $\mathrm{C}^{+} ; \mathrm{O}$, prototrophic revertant. Arrows indicate intraperitoneal injection of adenine. Mean values and the standard deviation of three independent experiments.

\section{In vivo growth of adenine auxotrophs}

Recently isolated encapsulated strains of adenine-dependent mutants, i.e. ade II-4; ade I-I; ade I-2, were tested for virulence in the conventional way, as described for strains already studied (Ivánovics \& Marjai, I964). In spite of an adenine intake, animals infected with $10^{6}$ spores either lived to the end of the experiment or, when they died, their heart blood did not yield colony-formers. By contrast, 20 spores of their prototrophic revertants killed mice regularly.

Figure I shows a short-term experiment with strain ade $\mathrm{II}-3 \mathrm{C}^{+}$and its prototrophic 
revertant, when the proliferation of bacteria was followed in the peritoneal cavity of the mouse. There was an initial decrease in colony count, even in the case of the revertant, which was, however, followed by rapid multiplication of the prototrophic bacteria. By comparison, the number of adenine-dependent bacilli gradually declined after the abrupt initial phase, in spite of the intensive adenine intake. In addition to the data shown by the curves, mice sacrificed at 48 to $72 \mathrm{hr}$ after infection with ade II-3 $\mathrm{C}^{+}$still contained $\mathrm{IO}^{2}$ to $\mathrm{IO}^{3}$ colony-formers $/ \mathrm{ml}$. of peritoneal washings. Nevertheless, no deaths occurred which could be attributed to generalized infection. Animals in these experiments were killed by a delayed toxic effect of adenine, as indicated by a control group receiving adenine alone in which more than half of the mice died between the 3 rd and 4 th day.

It appeared reasonable to make similar experiments with adenine in an oily suspension $(0.5 \mathrm{ml}$.) administered subcutaneously in a single dose, rather than in several doses given intraperitoneally. In a series of experiments, 2,3 and $8 \mathrm{mg}$. adenine were given as single doses to mice infected with $5 \times 10^{6}$ pre-germinated spores. The initial colony count amounted to 2 to $3 \times 10^{5} / \mathrm{ml}$. peritoneal washings, which declined considerably within 2 to $3 \mathrm{hr}$. This was followed by a gradual decline in the colony count by the 3 rd to $4^{\text {th }}$ day. It should, however, be stressed that a high proportion of mice given $8 \mathrm{mg}$. adenine died during the observation period without giving positive blood cultures.

There are two blocks in the biosynthetic pathway of adenine in strain ade II- $3 \mathrm{C}^{+}$, both caused by the lack of the enzyme adenylosuccinate lyase. The early block in the pathway, when fumaric acid is not split from SAICAR, was overcome by any of the purines, such as hypoxanthine. Theoretically, this should have a sparing effect on adenine demand, since the synthesis of guanylic acid is brought about directly via inosinic acid instead of by the conversion of adenylic acid to gunylic acid. This assumption, however, could not be substantiated by an experiment in which infected mice were given hypoxanthine + adenine ( $5 \mathrm{mg}$. each); none of the infected mice died of anthrax. Similarly, no enhancing effect was found when histidine, a product of ATPimidazole cycle, was given simultaneously with adenine + hypoxanthine.

In the experiments described so far, mice were infected by spores given a short germination period ( $30 \mathrm{~min}$ ) in $\mathrm{BCM}+$ adenine. Only a small proportion of these spores showed any sign of germination when inoculated into mice. As it can be seen from Fig. I, there was about a $\mathrm{I} \cdot 5 \log$ unit decrease in the colony count by the $3 \mathrm{rd}$ hour as compared with the initial value. In this early phase, before the germination of spores and encapsulation of the bacilli, the organisms appeared to be highly vulnerable to the defence mechanisms of the host. Indeed, only $2.5 \%$ of inoculated spores reached the exponential phase of multiplication.

This unfavourable lag in multiplication of bacteria suggested that it might be preferable to infect the mice with encapsulated vegetative bacilli instead of spores, and an experiment was made with encapsulated bacilli of strain ade $\mathrm{II}-3 \mathrm{C}^{+}$(Table 3 ). The colony count in mice not given adenine gradually decreased to as little as $\mathrm{r} \%$ of the initial value. By comparison, a high dose of adenine enhanced the multiplication of bacilli for $24 \mathrm{hr}$, although this high colony count in the peritoneal cavity was not associated with a bacteraemia. When blood samples $(0.02 \mathrm{ml}$.) were taken at autopsy and plated on nutrient agar, either they did not yield any colonies, or in a few cases only one or two colonies.

Table 4 shows the results of another experiment in which mice were infected with 
Table 3. Bacillus anthracis: colony counts in the peritoneal washings of mice infected with $4 \times 10^{5}$ colony-formers of heavily encapsulated bacilli from strain ade $1 \mathrm{I}-3 \mathrm{C}^{+}$, with and without adenine

Because of chain formation, the actual number of bacilli in the inoculum was about Io times greater than the colony count. In addition to the dead mice included in the Table, four mice died spontaneously on the 3 rd to 5 th day; their blood cultures were negative, and they had apparently died from the toxic effect of adenine. A control group of 7 mice given adenine alone died after the third day.

$\begin{array}{rcc}\text { Time } & \begin{array}{c}\text { Peritoneal washings: log. no. } \\ \text { colony-formers/ml. }\end{array} \\ \text { (hr) } & \begin{array}{c}\text { Without } \\ \text { adenine }\end{array} & \begin{array}{c}\text { With } 6 \mathrm{mg} . \\ \text { adenine in oil } \\ \text { subcutaneously }\end{array} \\ 0 & 4.30 & 4.20 \\ 2 & 3.74 & 4.69 \\ 4 & 3.00 & 5.69 \\ 8 & 3.15 & 5.66 \\ 12 & 2.69 & 5.84 \\ 24 & 2.00 & 5.08 \\ 48 & 0.00 & 4.95\end{array}$

Table 4. Bacillus anthracis: colony counts of peritoneal washings and the results of microscopic examination of peritoneal smears of mice infected with $10^{6}$ colony-formers of heavily encapsulated bacilli of strain ade $\mathrm{II}_{-3} \mathrm{C}^{+}+\mathrm{I} \mathrm{mg}$. adenine

\begin{tabular}{|c|c|c|c|}
\hline $\begin{array}{l}\text { Time } \\
\text { (hr) }\end{array}$ & $\begin{array}{l}\text { Further } \\
\text { intraperitoneal } \\
\text { injection of } \\
\text { adenine } \\
\text { (mg.) }\end{array}$ & $\begin{array}{l}\text { Log. } \\
\text { colony } \\
\text { count } / \mathrm{ml}\end{array}$ & Microscopic observations* \\
\hline o & $I \cdot 0$ & $5 \cdot 09$ & Well-stained encapsulated bacilli \\
\hline 2 & 0.5 & 4.30 & $\begin{array}{l}\text { Mostly chains with 2-8 encapsulated } \\
\text { bacilli; a proportion were poorly } \\
\text { stained; some empty capsules }\end{array}$ \\
\hline $4 \cdot 5$ & 0.5 & $4^{\cdot 0}$ & $\begin{array}{l}\text { Some well-stained bacilli in short chains; } \\
\text { many ghost-like forms }\end{array}$ \\
\hline 8 & 0.5 & $4 \cdot 2$ & $\begin{array}{l}\text { Proportion of poorly stained bacilli } \\
\text { increased }\end{array}$ \\
\hline 12 & 0.5 & $4 \cdot 3$ & $\begin{array}{l}\text { Poorly stained and ghost-like bacilli } \\
\text { increased in number }\end{array}$ \\
\hline 24 & 0.5 & $5 \cdot 0$ & $\begin{array}{l}\text { Beside well-stained bacilli disintegrated } \\
\text { and ghost-like forms prevailed }\end{array}$ \\
\hline $\begin{array}{l}36 \\
48\end{array}$ & $\begin{array}{l}\text { Nil } \\
\text { Nil }\end{array}$ & $\begin{array}{l}2 \cdot 9 \\
2 \cdot 6\end{array}$ & $\begin{array}{l}\text { Very few well-stained bacilli; many dis- } \\
\text { integrated and ghost-like forms }\end{array}$ \\
\hline
\end{tabular}

* Faintly or unevenly stained shrunken bacilli are referred to as 'ghost-like forms'. Most of these structures were encapsulated; many empty capsules were also seen.

encapsulated bacilli. On this occasion, however, a heavier infecting dose consisting of $10^{6}$ colony-formers $+\mathrm{I} \mathrm{mg}$. adenine was given intraperitoneally, and the intraperitoneal injection of adenine was continued for $24 \mathrm{hr}$. In addition to determination of colony counts, smears were taken from the peritoneal surface for microscopic examination.

A better insight was gained into the microscopic changes of inoculated bacilli 
when an extremely high dose of bacilli ( $10^{7}$ colony-formers $=$ about $10^{8}$ bacilli) was injected and the mice given adenine on a similar schedule (Table 4 ). In this experiment, most of the mice were alive at $32 \mathrm{hr}$ in spite of the considerable colony count in the peritoneal cavity. Blood samples from mice which were sacrificed or died in this experiment contained none or only a few colony-formers.

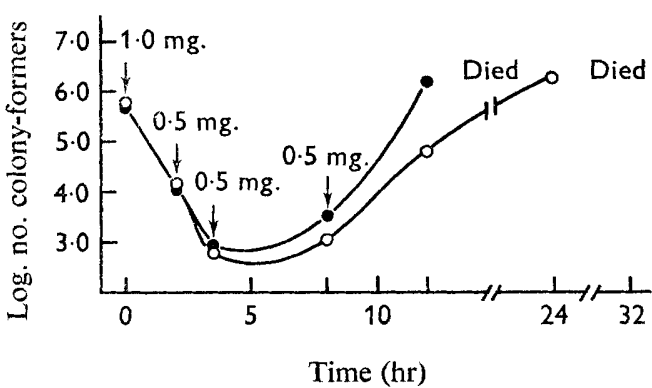

Fig. 2

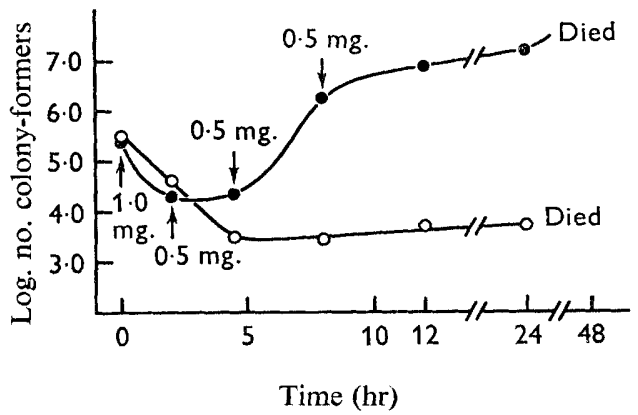

Fig. 3

Fig. 2. Bacillus anthracis: number of colony-formers in the peritoneal cavity of mice infected with $5 \times 10^{6}$ pre-germinated spores of strain pur-r. Geometric means of pooled data of three experiments. $O$, No hypoxanthine; hypoxanthine given. Arrows indicate the intraperitoneal injection of hypoxanthine.

Fig. 3. Bacillus anthracis: the number of colony-formers in the peritoneal cavity of mice infected with $5 \times 10^{6}$ pre-germinated spores of gua-I. Geometric means of pooled data of several experiments. $O$, No guanine;, guanine given. Arrows indicate the intraperitoneal injection of guanine.

Microscopic observation of the peritoneal smears showed that the long chains broke into smaller units within a few hours after infection. This was associated with a diminished intensity of staining of many of the bacilli, which was soon followed by a gradual disintegration of the organisms. The capsule can withstand disintegration better than the bacillus itself; this resulted in many empty capsules. Finally, after $24 \mathrm{hr}$, the whole microscopic field was filled with empty capsules, ghost-like structures and disintegrated remnants, with only a few well-stained bacilli. The accumulation of host cells in the abdominal cavity of the infected mouse was slight or moderate as compared with the number of bacilli present. Besides small lymphocytes and cells with lobulated nucleus, giant cells, probably monocytes containing some engulfed disintegrated bacilli, were seen in the smears.

The experiments dealt with so far were exclusively made with strain ade II $-3 \mathrm{C}^{+}$. The study of the growth of adenine-dependent strains in vivo was extended to other isolates belonging to group II; this resulted in identical observations about their virulence. None of the mice died of anthrax when injected with $5 \times 10^{6}$ spores intraperitoneally and with $5 \mathrm{mg}$. adenine in oil subcutaneously.

Isolates belonging to group I because of failure to form adenylosuccinate synthase were also found to be avirulent. Spores $\left(5 \times 10^{6}\right)$ of either of the strains ade $\mathrm{I}-\mathrm{I} \mathrm{C} \mathrm{C}^{+}$or ade $\mathrm{I}-2 \mathrm{C}^{+}$did not grow in the peritoneal cavity sufficiently to produce toxic death by anthrax bacteraemia, although the mice were given toxic doses of adenine. In comparison, spores of the prototrophic revertants of the above mentioned isolates grew rapidly in the body of the mouse, causing death. 


\section{In vivo growth of other purine auxotrophs}

Both the strains pur-I and gua-I appeared to be highly virulent when examined by a conventional test for virulence (Ivánovics \& Marjai, 1964). Their virulence could not be related to a 'leaky-ness' in their purine requirement, since their growth responses to the specific metabolites showed a similar intensity to those of the adenine-dependent mutants. In vivo multiplication of the above-mentioned strains was examined in the same way as the adenine-dependent mutants (Fig. 2, 3). The colony count of strain pur-I showed a rapid decline in the initial phase of the experiment followed by an increase in number. All the mice died of generalized anthrax within 24 to $32 \mathrm{hr}$, even when the infection was not associated with administration of hypoxanthine. Only a moderate enhancing effect on the course of infection was given by hypoxanthine.

\section{Table 5. Bacillus anthracis: total number of colony-formers of strain gua-I in the peritoneal cavity and the blood circulation of infected mice}

\footnotetext{
Mice were infected with $5 \times 10^{6}$ pre-germinated spores of strain gua-1; the mice were not given guanine. Total colony count in the blood circulation was calculated on the base of body weight of animals. Total blood: one-twelfth of body weight.
}

Log values of geometric mean and its

$\begin{array}{cc}\begin{array}{c}\text { Time } \\ \text { (hr) }\end{array} & \begin{array}{c}\text { No. of } \\ \text { mice }\end{array} \\ 5 & 2 \\ 7 \cdot 5 & 1 \\ 20 & 2 \\ 24 & 5 \\ 32 & 3\end{array}$
standard deviation

$\begin{array}{cc}\text { Peritoneal cavity } & \text { Blood circulation } \\ 3.84 \pm 0.15 & 2.77 \pm 0.45 \\ 3.50 & 2.62 \\ 5.01 \pm 0.17 & 5.29 \pm 0.41 \\ 4.52 \pm 0.34 & 5.89 \pm 0.89 \\ 5.04 \pm 0.32 & 6.74 \pm 0.48\end{array}$

Curves depicting the progress of infection with strain gua-I showed a somewhat different pattern from that observed with the pur-auxotroph. The enhancing effect of guanine was very marked, although both groups of mice, whether or not treated with guanine, died 24 to $48 \mathrm{hr}$ after infection. The marked enhancing effect of guanine indicated a shortage of this base in the peritoneal cavity. Nevertheless, the survival times of mice in the group without guanine were only a few hours longer than that of the group given guanine. Blood samples, taken a few hours after infection from mice not given guanine, yielded auxotrophic bacteria. A group of mice, each injected with $5 \times 10^{6}$ pre-germinated spores of strain gua-I, had the bacterial count determined in the peritoneal cavity as well as in the blood of individual mice at intervals (Table 5). Mice sacrificed as early as $5 \mathrm{hr}$ after infection already had a bacteraemia. The total number of colony-formers in the whole blood circulation, however, was significantly lower than that in the peritoneal cavity. The colony counts were about the same by $7.5 \mathrm{hr}$ after infection; bacilli in the blood finally outnumbered those in the peritoneal cavity. On the basis of this finding, one may suppose that the guanine supply in blood was ample to support growth of the bacilli to a degree fatal to the host. However, most of the mice died within $24 \mathrm{hr}$; survival after this period may have been due to individual variation in susceptibility of the mice. This may also account for the relatively low total number of bacilli circulating in the blood in the later part of the experiment. 


\section{Toxin production by adenine-dependent mutants}

The complete lack of virulence of strains belonging to both groups of adeninedependent mutants could not be related to any impairment in capsule formation (Table 4). Besides capsule production, another 'aggressin' produced by Bacillus anthracis is an oedema-producing toxin which later in the course of disease acts to kill the host (Smith, Keppie \& Stanley, 1955). The question arose: could the lack of virulence of adenine-dependent strains be related to a loss of toxin production associated with mutation at the adenine locus? To examine this possibility toxin production in vitro by adenine-dependent strains belonging to both groups I and II was compared with that of the prototrophic strain $\mathrm{VC}^{+}$. Several batches of culture filtrates were obtained from each strain and tested for ability to produce an oedematous lesion in guinea-pig skin and to give a precipitate in the agar diffusion method. All the filtrates appeared to be identical in potency either in vivo or in vitro. After $20 \mathrm{hr}$, the highest dilution of toxin preparation which just produced a detectable oedematous reaction was between $\mathrm{I} / 4$ and $\mathrm{I} / 8$, with the different filtrates. There was no significant difference in the potency of the filtrates from any of the adenine-dependent mutants and from the prototrophic parent stain; identical results were obtained with agar diffusion tests. The oedema-producing action of the filtrate was neutralized with horse hyperimmune serum effective in the agar diffusion test.

Table 6. Bacillus anthracis: growth of strain adeII-3 in the presence of heparinized plasma obtained from mice injected subcutaneously with $5 \mathrm{mg}$. adenine in oil

Colony counts: in BCM without plasma, $2.6 \times 10^{4}$; in BCM+adenine, $10 \mu \mathrm{g} . / \mathrm{ml} ., 4.7 \times 10^{6}$. The numbers in the Table represent the colony counts after an inoculum of $2.5 \times 10^{4}$ colony-formers $/ \mathrm{ml}$. There was considerable chain formation in tubes at 2.5 to $24 \mathrm{hr}$, and in $\mathrm{BCM}+$ adenine Io $\mu \mathrm{g} . / \mathrm{ml}$.

$\begin{array}{cc}\begin{array}{c}\text { Time of } \\ \text { sampling } \\ \text { (hr) }\end{array} & \begin{array}{c}\text { Number of colony- } \\ \text { formers/ml. } \dagger \text { after }\end{array} \\ 24 \mathrm{hr} \text { incubation }\end{array}$

* Plasma from animals before inoculation of adenine.

$\dagger$ Colonies counted on $\mathrm{BCM}+$ adenine.

\section{Availability of adenine in the body of mice given adenine}

Even a generous supply of adenine to the mice did not support that degree of growth of the adenine-dependent bacilli necessary to kill the mice. Whether lack of adenine in the host or some other factor was involved in making the bacilli incapable of invading the blood stream was open to question. Attempts were therefore made to determine the adenine concentration in the bodies of mice given adenine. Apart from the difficulties of using chemical methods to determine adenine in the body fluids, preference was given to microbiological assay for two reasons: (i) it is simple to perform; (ii) the total utilizable metabolites are assayed, since the adenine-dependent strain can use, in addition to adenine itself, its nucleoside readily and its nucleotides 
poorly. When mice, given I mg. adenine intraperitoneally, were sacrificed in pairs after $2 \mathrm{hr}$ and the pooled washings of their peritoneal cavities assayed, a total of 30-35 $\mu \mathrm{g}$. adenine was found. Thus, about $3 \%$ of the adenine injected was detected at this time. Repeated injections of $0.5 \mathrm{mg}$. adenine at intervals maintained a very low total amount (about 2 to $3 \mu \mathrm{g}$.) in the pooled washings. Nevertheless, the amount of adenine in the peritoneal fluid, the volume of which was not more than a few tenths of a millilitre, must have been enough to support growth of the bacilli. After injection of $5 \mathrm{mg}$. adenine, heparinized plasma samples were assayed for adenine, and the concentration of utilizable adenine metabolites detected with strain ade II-3. It can be seen from Table 6 that there was about the same growth of the inoculated bacilli in the sample taken $2 \mathrm{hr}$ after the injection of adenine as was found in BCM + adenine $10 \mu \mathrm{g}$. $/ \mathrm{ml}$. Substantial growth of bacilli was still supported by the plasma sample taken Io hr after injection; there was also a slight growth of bacteria in the $24 \mathrm{hr}$ sample.

It can be concluded from these results that there was rapid elimination of utilizable adenine from the body of the mouse, although its concentration appeared to be sufficient to support some growth of bacilli in the peritoneal cavity and in the blood stream, particularly when a heavy inoculum of encapsulated bacilli was used for infection. No substantial growth of gua-I mutant was observed in cultures made with the plasma of normal mice. Heating the plasma samples (at $55^{\circ}$ for $30 \mathrm{~min}$.) before their addition to the assay system did not change the result observed with unheated plasma.

\section{DISCUSSION}

The literature on the virulence of auxotrophic mutants of Gram-negative pathogens has been reviewed by Burrows (1960), Panos \& Ajl (1963) and Braun (1965); only relevant aspects will be discussed here. It can be stated that, according to the specific requirement of individual auxotrophs, they may either retain or lose their virulence. Availability of the required metabolite in vivo is apparently a crucial point in determining virulence. Thus, generally speaking, mutants which require either amino acids or vitamins, of which there is an ample source in the host, grow readily in vivo. There are, however, seemingly contradictory observations about the virulence of purine-requiring auxotrophs. Gowen, Stadler, Plough \& Miller (1953) found that some of their adenine-dependent isolates of Salmonella typhimurium were of low virulence or avirulent, in contrast to others which displayed considerable virulence. Unfortunately, no data were presented about the precise block in the purine pathway of these auxotrophic strains; all their strains were referred to as 'adenine mutants'. The purine-requiring mutants of Salmonella typhi isolated and studied by Bacon, Burrows \& Yates (I950 $a, b$, 195I) were also only partially specified. It appears that some of these strains were defective either in the early part of purine synthesis or in the conversion of inosinic acid to guanylic acid. The low virulence of some of these auxotrophs was enhanced by injection of hypoxanthine simultaneously with the bacterium (Bacon et al. 195I). A similar observation was described by Formal, Baron \& Spilman (1954) for a xanthine-dependent mutant of S. typhi. A purine auxotroph of Pasteurella pestis was studied by Burrows (1955), the growth requirement of which was met by hypoxanthine; it appeared to be of low virulence when bacteria only were injected, but its virulence was restored by administering hypoxanthine to the host when challenged with the mutant. So far as we know, no study has been made with an auxotrophic 
mutant of any pathogenic bacterium with a specific requirement for adenine; that is, with strains in which the conversion of inosinic acid to adenylic acid is blocked.

It was reported from this laboratory (Ivánovics \& Marjai, 1964) that purine auxotrophs of Bacillus anthracis varied in virulence according to the site of the block in the purine pathway. In the present work we succeeded in isolating adenine-dependent mutants which could be grouped into two genotypes by their biochemical characteristics. Both groups of mutants, lacking either adenylosuccinate synthase or adenylosuccinate lyase, were unable to proliferate in the peritoneal cavity of the mouse, although the animals were injected with a large inoculum of spores and were given a toxic dose of adenine at the time of challenge. When a heavy inoculum of encapsulated bacilli was used, under similar experimental conditions as for the spore inoculum, a massive invasion of blood by the bacilli was not observed, although a certain number of viable organisms persisted in the peritoneal cavity. It seems that the limited number of bacilli which reached the blood stream, despite the presence of adenine in the blood which might support their growth, were hindered in proliferation by the defence mechanisms of the host. Apparently, adenine-dependent $B$. anthracis organisms are highly susceptible to these defence mechanisms, a supposition corroborated by their rapid disintegration in the peritoneal cavity.

In contrast to the adenine-dependent mutants of Bacillus anthracis, purine auxotrophs, either defective in the early part of the purine pathway or in the conversion of xanthylic acid to guanylic acid, grew readily in the mouse peritoneal cavity, leading to a generalized infection and death. A standard infecting dose of spores killed a mouse even without an exogeneous supply of purine; however, the course of infection was augmented by adequate administration of purine.

It is of interest that, although the multiplication of the guanine-dependent mutant in the peritoneal cavity was moderate, nevertheless the bacilli readily invaded the blood stream in the early period of infection. Bacilli which reached the blood stream multiplied freely and outnumbered the bacilli present at the site of infection. It is open to question how this mutant had access to the purine needed for its proliferation in the body. Formal et al. (1954) were not able to detect the presence of metabolites needed by their xanthine-dependant mutant of Salmonella typhi in the peritoneal fluid of mice. We also failed to demonstrate an ample availability of guanine in the blood of plasma this host. Nevertheless, a guanine-dependent strain of Bacillus anthracis grew readily both in the mouse peritoneal cavity and blood stream. A minimal amount of guanine and other purines in the peritoneal cavity may originate from injury caused by injection of the inoculum. When a small amount of sterile salt solution was injected intraperitoneally into a mouse, this evoked an accumulation of material absorbing at $260 \mathrm{~m} \mu$ in the peritoneal washings (unpublished observation). Apparently, this minimal amount of purine was capable of initiating growth of germinated $\mathrm{B}$. anthracis spores; the subsequent multiplication of the bacilli in the peritoneal cavity, and their invasion of the blood stream, may cause an influx of purine to the site of infection and to the blood stream from damaged host cells and tissues.

In view of the evidence presented above, it does not seem reasonable to ascribe the lack of virulence of the adenine-dependent mutants of Bacillus anthracis entirely to shortage of available adenine in the host. It may be that there is, in addition to capsule and toxin production, an intrinsic entity necessary for the proliferation in vivo of $B$. anthracis, and that this function is not present in the adenine-dependent mutants. 
The authors are very much indebted to Professor H. Smith (Birmingham) for the unpublished formula of his medium and for a generous gift of anthrax antitoxic serum. We thank Dr Haruo Momose (Kawasaki, Japan) for the sample of adenylosuccinic acid he kindly gave us. Thanks are also due to Dr K. Csiszár for his participation in part of this investigation, and to Dr J. McGeachie (Royal Infirmary, Glasgow) for his help in preparing the manuscript.

\section{REFERENCES}

Bacon, G. A., Burrows, T. W. \& Yates, M. (I950a). The effect of biochemical mutation on the virulence of Bacterium typhosum. The induction and isolation of mutants. Br. J. exp. Path. 3r, 703.

Bacon, G. A., Burrows, T. W. \& Yates, M. (1950 $b$ ). The effect of biochemical mutation on the virulence of Bacterium typhosum. The virulence of mutants. Br. J. exp. Path. 3I, 7I4.

Bacon, G. A., Burrows, T. W. \& YATes, M. (195I). The effect of biochemical mutation on the virulence of Bacterium typhosum. The loss of virulence of certain mutants. Br.J. exp. Path. 32,85 .

BENNET, E. L. (1953). Incorporation of adenine into nucleotides and nucleic acids of $\mathrm{C}_{57}$ mice. Biochim. biophys. Acta I1, 487.

Bratton, C. \& MARshall, E. K. Jun. (1939). A new coupling component for sulfanilamid determination. J. biol. Chem. 128, 573.

Braun, W. (I965). Bacterial Genetics, 2nd ed. Philadelphia and London: W. B. Saunders Co.

Brown, G. B., Roll, P. M. \& Plentl, A. A. (1947). Studies on the metabolism of adenine. Fedn Proc. Fedn Am. Socs exp. Biol. 6, 517.

Burrows, T. W. (1955). The basis of virulence for mice of Pasteurella pestis. Symp. Soc. gen. Microbiol. 5,52 .

Burrows, T. W. (1960). Biochemical properties of virulent and avirulent strains of bacteria: Salmonella typhosa and Pasteurella pestis. Ann. N.Y. Acad. Sci. 88, I 125.

CARTER, C. E. \& COHEN, L.H. (1956). The preparation and properties of adenylosuccinase and adenylosuccinic acid, $J$. biol. Chem. 222, 17.

Cziszár, K. \& Ivánovics, G. (1965). Transduction in Bacillus subtilis. Acta microbiol. hung. 12, 73.

Demerec, M., Adelberg, E. A., Clark, A. J. \& Hartman, P. E. (I966). A proposal for a uniform nomenclature in bacterial genetics. Genetics 54, 61 .

Formal, S. B., Baron, L. S. \& SpIlmaN, W. (1954). Studies on the virulence of a naturally occurring mutant of Salmonella typhosa. J. Bact. 68, i 17.

Giles, N. H., Partridge, C. W. H. \& Nelson, N. J. (1957). The genetic control of adenylosuccinase in Neurospora crassa. Proc. natn. Acad. Sci. U.S.A. 43, 303.

Gollub, E. G. \& Gots, J. S. (I959). Purine metabolism in bacteria. VI. Accumulation by mutants lacking adenylosuccinase. J. Bact. 78, 320.

GoTs, J. S. \& GolluB, E. G. (1957). Sequential blockade in adenine biosynthesis by genetic loss of an apparent bifunctional deacylase. Proc. natn. Acad. Sci. U.S.A. 43, 826.

Gots, J. S. \& Love, S. H. (I954). Purine metabolism in bacteria. II. Factors influencing biosynthesis of 5-amino-4-imidazolecarboxamide in Escherichia coli. J. biol. Chem. 210, 395.

Gowen, J. W., Stadler, J., Plough, H. H. \& Miller, H. N. (I953). Virulence and immunizing capacity of Salmonella typhimurium as related to mutation in metabolic requirements. Genetics 38,531 .

IVÁNOvics, G. (1962). The pathogenicity of Bacillus anthracis lysogenic with mutant of phage W. J. gen. Microbiol. 28, 87 .

IVÁNOvics, G. (I964). Temperature sensitivity of mutants of Bacillus anthracis caused by a block in thymine-nucleotide synthesis. J. gen. microbiol. 35, 299.

Ivánovics, G. \& MARJAI, E. (1964). Die Virulenz der Purin-Auxotrophen des Bacillus anthracis. Zentbl. Bakt. ParasitKde (Abt I) 193, 363.

Ivánovics, G., VARga, J. \& MarJaI, E. (1963). Auxotrophs of Bacillus anthracis. Acta microbiol. hung. 10, 409.

Lieberman, I. (1956). Enzymic synthesis of adenosine-5'-phosphate from inosine-5'-phosphate. J. biol. Chem. 223, 327. 
Lowry, O. H., Rosebrough, N. J., Farr, A. L. \& Randall, R. L. (I95I). Protein measurement with the Folin phenol reagent. J. biol. Chem. 193, 265.

Lukens, L. N. \& Buchanan, J. M. (1959). Biosynthesis of the purines. XXIII. The enzymatic synthesis of N-(5-amino-I-ribosyl-4-imidazolylcarbonyl)-L-aspartic acid 5'-phosphate. J. biol. Chem. 234, I79I.

Panos, C. \& AJl, S. J. (1963). Metabolism of micro-organisms as related to their pathogenicity. A. Rev. Microbiol. 17, 297.

Philips, F. S., Thiersch, J. B. \& Bendich, A. (1952). Adenine intoxication in relation to in vivo formation and deposition of 2,8-diuxyadenine in renal tubules. J. Pharmac. exp. Ther. 104, 20.

RASKa, S. B. (1946). Studies on the effect of purines on metabolism. J. biol. Chem. 165, 743.

Ravel, J. M., EAKIN, R. E. \& ShIVE, W. (1948). Glycine, a precursor of 5(4)-amino-4(5)-iminazolecarboxamide. J. biol. Chem. 172, 67.

Sargeant, K., Stanley, J. L. \& Smith, H. (I960). The serological relationship between purified preparation of factor I and II of the anthrax toxin produced in vivo and in vitro. J. gen. Microbiol. 22, 219.

Schwarz, M. R. \& Rieke, W. O. (1963). The utilization in vivo of mouse nucleic acid metabolite labelled with radioactive precursor substances. Lab. Invest. 12, 92.

Smith, H., Keppie, J. \& Stanley, J. L. (I955). The chemical basis of the virulence of Bacillus anthracis. V. The specific toxin produced by B. anthracis in vivo. Br. J. exp. Path. 36, 460.

Thorne, C. B. \& Belton, F. C. (1957). An agar diffusion method for titrating Bacillus anthracis immunizing antigen and its application to a study of antigen production. J. gen. Microbiol. $\mathbf{x}$, 505. 